\title{
What follows what? Relations between economic indicators, economic expectations of the public, and news on the general economy and unemployment in Germany,
} 2002-2011

\author{
Lischka, Juliane A
}

\begin{abstract}
This study aims to understand dynamic agenda-building and agenda-setting processes between realworld indicators, public expectations (PEs), and aggregated news on the general economy and unemployment for the four most popular general news outlets in Germany from 2002 to 2011: two public service, a commercial news show, and a tabloid newspaper. Vector autoregression models and Granger causality tests reveal that (1) news tone (NT) relates to real-world indicators; (2) PEs for the general economy and unemployment are partly set by the tone of news on the general economy, especially during recession times; and (3) PEs can forecast the future real-world economy.
\end{abstract}

DOI: https://doi.org/10.1177/1077699015574098

Posted at the Zurich Open Repository and Archive, University of Zurich

ZORA URL: https://doi.org/10.5167/uzh-112838

Journal Article

Accepted Version

Originally published at:

Lischka, Juliane A (2015). What follows what? Relations between economic indicators, economic expectations of the public, and news on the general economy and unemployment in Germany, 2002-2011. Journalism and Mass Communication Quarterly, 92(2):374-398.

DOI: https://doi.org/10.1177/1077699015574098 
What Follows What?

Relations between Economic Indicators, Economic Expectations of the Public, and News on the General Economy and Unemployment in Germany, 2002-2011

Juliane A. Lischka

Institution: Institute of Mass Communication and Media Research, University of Zurich

Address: $\quad$ Andreasstrasse 15, CH-8050 Zurich, Switzerland

Phone: $\quad$ +41(0) 446352075

Fax: $\quad+41(0) 446344934$

E-mail: $\quad$ j.lischka@ipmz.uzh.ch

\begin{abstract}
This study aims to understand dynamic agenda building and agenda setting processes between real-world indicators, public expectations, and aggregated news on the general economy and unemployment for the four most popular general news outlets in Germany from 2002 to 2011: two public service, a commercial, and a tabloid news outlet. Vector autoregressive and Granger causality tests reveal that (1) news tone relates to real-world indicators, (2) public expectations for the general economy and unemployment are set by the tone of news on the general economy, especially during recession times, and (3) public expectations can forecast the future real-world economy.
\end{abstract}


Author's note: This study was conducted for the project, “The impact of economic media coverage on business expectations and advertising expenditures in Switzerland and Germany," funded by the Swiss National Science Foundation. 


\section{Introduction}

Economic news not only reports on the economy but also affects its development. Public economic opinion such as consumer confidence is subject to media effects, ${ }^{1}$ an early indicator of consumption ${ }^{2}$ and of the economy. ${ }^{3}$ The economy is a "permanently salient issue of the public discourse" ${ }^{4}$ and news coverage. Yet few studies simultaneously consider dynamic agendabuilding and agenda setting processes between economic news, public opinion, and the economy. ${ }^{5}$

This study aims to understand the relations between economic news coverage on news on the general economy and employment, changes in public expectations about the general national economic and unemployment developments, and the development of corresponding economic indicators. We ask the following research questions:

- Is the news set by public expectations and/or economic indicators?

- $\quad$ To what degree are public expectations set by the news?

- $\quad$ Are economic indicators forecast by the news and/or public expectations?

We address these questions by applying vector autoregressive (VAR) models to monthly time series data on the news tone, consonance, and volume of four most popular news outlets in Germany, public expectations, and economic indicators on the general state of the economy and unemployment for Germany from January 2002 to June 2011. Since time lags in agenda setting are expected to appear within quarters, ${ }^{6}$ analysis on monthly frequency is applied.

This aggregate analysis approach combining secondary data assumes collective news effects on the public. According to the concept of collective media effects, news effects are repeated 
by follow-up conversation to non-users and therefore media users and non-users develop similar economic expectations. ${ }^{7}$

\section{Literature Review}

Impact of Public Expectations and Economic Indicators on News Coverage. Economic news relies on real-world cues such as economic indicators or public opinion of the economy. Which of the two is more potent for news coverage has not yet been clarified. ${ }^{8}$ Behr and Iyengar reveal that news coverage is more likely influenced by reality than by public opinion. ${ }^{9}$ Later, Wu et al. support this result. ${ }^{10}$ However, in periods with an economic downturn, public opinion can forecast economic news better than the real-world economy. In Blood and Phillips' study, ${ }^{11}$ the effect of changes of public opinion on news on the general economy are reported across time. Here, during an upturn and a stable period, public opinion had an effect on news whereas leading economic indicators had no effect. Further, economic news is often characterized as negative. ${ }^{12}$ Changes in news coverage are found to be asymmetric, favoring the coverage of negative economic developments. ${ }^{13}$ Nadeau et al. ${ }^{14}$ show that economic indicators (change in unemployment, change in inflation, the oil shock in 1979/80) and elite judgments have an impact on the news - and that the news interpret economic conditions. The dramatic event of the oil shock had an especially strong impact on news in their study. Also different affectedness of employment may cause different levels of news salience. ${ }^{15}$ In the study by Starr, ${ }^{16}$ consumer sentiment and the unemployment rate have a stronger forecasting ability for news than do other real-world indicators such as the Federal Funds rate, consumption, inflation and stock prices. However, Soroka ${ }^{17}$ proves that very little unemployment news variation can be explained by the unemployment rate. He argues that a certain amount of noise, 
the interests of the journalists and third parties as well as the salience of other issues may produce this result. Similarly, Nadeau et al. ${ }^{18}$ discuss the idea that journalistic interpretation of real-word events may lead to weak relations between economic news and economic indicators. The news pattern in recession periods is an excessive increase of negative news caused by real-world developments. Journalists may act in a "regular mode," with greater interpretative autonomy, during non-recession periods that declines during recession periods. Hence, we ask the following.

RQ1: Do real-world indicators or public expectations forecast economic news coverage better during economic recessions than during non-recession periods?

Impact of News Coverage and Economic Indicators on Public Expectations. Although many researchers have revealed that news coverage influences people's agendas and views about the economy ${ }^{19}$ and traditional news media still affect the public agenda, ${ }^{20}$ the public can also obtain economic information from their daily lives, experiencing real-world cues that supersede the influence of media coverage. ${ }^{21}$ The obtrusive contingency hypothesis expects agendasetting effects to decrease with personal experience of an issue. Media may set the agenda for abstract, unobtrusive topics. ${ }^{22}$ Obtrusive topics are those that "people can have personal experience" 23 with and that relate to "events in their daily life." ${ }^{24}$ Previous research a priori defines unemployment as an obtrusive issue, whereas the national gross domestic product (GDP) can be defined as either obtrusive or unobtrusive. ${ }^{25}$ For national economic topics, indicators in people's lives such as the bustle on shopping streets or the construction activity in a city can influence economic sentiment. Still, only when the news reports about economic issues can these be grasped as social problem and expectations for the economic development in a 
country be developed. For unemployment, $\mathrm{Mutz}^{26}$ finds that personal experience affects the evaluation of the individual employment situation whereas, at a national level, economic news affects the evaluation of unemployment as a social problem. Hagen ${ }^{27}$ argues that unemployment contains personal, egocentric (fear of losing one's job) and sociotropic (national problem) aspects, and finds that the news affects the perception of unemployment as an important national problem but is not likely to engender the fear that one will personally become unemployed. Yet both the general state of the economy and the increase in unemployment can affect personal life. Therefore, we understand the general state of the economy and national unemployment development as potentially obtrusive topics and expect the following according to the obtrusive contingency hypothesis.

H1: Real-world indicators forecast public expectations better than does news coverage.

National unemployment development is a lagging indicator of the economy, i.e., follows changes in the general economic situation. ${ }^{28}$ Hence, when the public develops national unemployment expectations as opposed to current unemployment evaluation, the general state of the economy may be considered as well. Therefore, we test the following.

$\mathrm{H} 2$ : An indicator on the general economy can better forecast public unemployment expectations than can unemployment numbers.

According to the concept of collective media effects, media users and non-users develop similar economic expectations though follow-up conversation. ${ }^{29}$ Yet a high degree of news consonance across outlets is crucial to the measurement of collective news effects. ${ }^{30}$ Hence, we test the interaction effect.

H3: The higher the news consonance, the stronger are news effects on public expectations. 
Shehata and Strömbäck find no short-term agenda-setting effects for the perceived importance of unemployment as "important political issue today," and suppose that chronic accessibility due to high news salience prevents an effect. ${ }^{31}$ However, Soroka ${ }^{32}$ expects that media influence on the public decreases as unemployment increases since more people then have their own experiences with unemployment, i.e., obtrusiveness and the perception of an egocentric problem increases. ${ }^{33}$ This is why personal experience creates similar economic expectations among media users and non-users. ${ }^{34}$ Hence, we test the interaction effect.

H4: The higher the unemployment numbers, the smaller the effect of news coverage on public expectations.

During the financial crisis, economic news served as the dominant source for the public when it was almost impossible for people to accurately evaluate economic issues. ${ }^{35} \mathrm{Wu}$ and Cole$\operatorname{man}^{36}$ and Hester and Gibson, ${ }^{37}$ using the examples of presidential candidates and the economy respectively, show that negative information has a more powerful public agenda-setting effect than does positive information. Wu et al. ${ }^{38}$ reveal that, in a recession, news has a stronger effect than the real economic situation on public expectations. More attention may be given to economic news during a recession to assess whether someone's own employment situation may be affected. As the need for orientation increases, the public pays more attention to economic news ${ }^{39}$ and issue salience increases as a result. ${ }^{40}$ Hence, we expect the following.

H5: News coverage forecasts changes in public expectations better during recessions than during non-recession times. 


\section{Impact of News Coverage and Public Expectations on Economic Indicators.}

Grossarth-Maticek and Mayr ${ }^{41}$ find that counts of the word "recession" in German newspapers can somewhat forecast the German gross domestic product (GDP). This relation should be moderated by economic decision making, which is influenced by public opinion. Wu et al. ${ }^{42}$ show that public sentiment from two to four months ago predicts economic performance. Therefore, both belief shocks ${ }^{43}$ and self-fulfilling expectations ${ }^{44}$ can move the economy. Expectation-driven business cycles explain changes in the economy through changes in economic expectations, which are caused by news shocks: “Empirically, news shocks about future productivity growth [...] induce an expansion in aggregate consumption, investment, employment, output and stock prices." ${ }^{45}$ Hence, false announcements of the macroeconomic development can affect economic growth. ${ }^{46}$

Iyengar and Kinder ${ }^{47}$ argue that, when making decisions, recipients rely on those topics that are most salient to them. After establishing attitudes and expectations, these should affect intention and behavior according to the theories of reasoned action and planned behavior. ${ }^{48}$ For example, TV evening news sentiment can predict private consumption..$^{49}$ This comprises the micro explanation of why consumer sentiment on the economy is considered an early indicator of the economy. ${ }^{50}$ Therefore, we propose the following hypotheses. 
H6: Public expectations can forecast indicators on the general state of the economy.

H7: A forecasting ability of public expectations on indicators on the general state of the economy is positively moderated by news coverage.

\section{Methodology}

The German Case. This study analyses economic news coverage by three television news shows and a newspaper with the largest audience in Germany, thereby representing Germany's pluralistic media structure. According to Hallin and Mancini, ${ }^{51}$ the German media system belongs to the Northern European or democratic corporatist model, with high newspaper circulation compared with that of other countries. Nevertheless, the reach of daily newspapers has been decreasing since the 1990s, dropping to $44 \%$ in 2010 from 54\% in 2000, whereas TV reached 86\% (85\%) of the German population in $2010(2000) .{ }^{52}$ In Germany, the quantity of economy news coverage in newspapers and TV has increased during the last two decades, ${ }^{53}$ as it has in Europe generally. ${ }^{54}$ Therefore, we consider German TV and newspaper media outlets a good European example for researching economic news.

The periods of the first quarter 2003 to the third quarter 2004 and the second quarter 2008 to the first quarter 2009 comprise recessions in Germany. ${ }^{55}$

News Outlet Selection. The news outlet with the largest audience in terms of reach (9.62 million and 9.14 million viewers in 2002 and 2011 respectively) is the major evening news show Tagesschau, a public service broadcast, followed by the major evening news show heute (5.17 million and 3.97 million viewers in 2002 and 2010 respectively), another public service broadcast. ${ }^{56}$ During the observation period, the reach of a major commercial broadcaster's evening 
news, RTL aktuell (3.89 million and 3.91 million viewers in 2002 and 2010 respectively ${ }^{57}$ ), exceeded that of heute. The fourth most important news outlet in terms of circulation is the commercial daily tabloid, BILD, whose circulation is in decline (4.05 million and 2.94 million in 2002 and 2010 respectively $\left.{ }^{58}\right)$.

The TV news shows provide general evening news. In the public service news shows, $70 \%$ of the content is dedicated to political and economic news. ${ }^{59}$ About $40 \%$ of the commercial news show, RTL aktuell, consists of political and economic news, the rest consisting of sports, human interest or celebrity stories. BILD is not specialized in providing economic news and does not have a business news section but is a "prototypical representative of tabloid journalism."60 Yet its news is found to influence economic sentiment. ${ }^{61}$ Shehata ${ }^{62}$ finds that TV news and tabloid newspapers display greater agenda-setting effects than other print media news.

Therefore, the news outlet selection covers the repertoire of many Germans and allows the disclosure of collective agenda-setting effects on aggregate level.

\section{Data.}

News Coverage. The news content data for public service and commercial broadcasters and the tabloid for the observation period from January 2002 to June 2011 ( $\mathrm{n}=114$ months) are kindly provided by the research company Media Tenor. The unit of analysis is each print article and TV report on economic topics ${ }^{63}$ referring to Germany on TV news shows and in the first three pages of the selected newspaper, since it does not hold a separate business news section. Except for the weather forecast, TV news shows are coded in their entirety. This study selects reports and articles dealing with the topics of national income, gross national product (GNP), GDP, the general economic situation, and economic growth for news on the general 
economic situation $(\mathrm{N}=4,152)$. Employment news comprises reports and articles on employment, unemployment, occupation, apprenticeships, labour force participation rate, the professional education system, and the professional qualification of the population $(\mathrm{N}=4,806)$. Total observations on the general economy (employment) amount to 1,095 $(1,148)$ for Tagesschau, 1,267 $(1,100)$ for heute, 711 (996) for RTL aktuell, and 1,079 (1,562) for BILD.

Economic news coverage is measured using three variables: the average tone of all economic news reports - news tone (NT), the degree of news tone consonance as the inverse standard deviation of news tone - news tone consonance (NC: higher values reflect a more homogeneous NT), and the sum of all reports - news volume (NV) on the general economy and employment. NT and NC measure journalistic interpretation, NV measures journalistic selection. The data is aggregated as means (NT, NC) and sums (NV) per month for the four news outlets considered. To take the mean of NT assumes that the news outlets report similarly. Although news outlets differ from each other in levels of NT-especially the tabloid newspaper BILD employs more positive NT after 2007 compared with TV news-NT and NC of the news outlets share common trends over time, i.e., are cointegrated.$^{64}$ Therefore, and because of the goal to reveal collective news effects, we consider taking the mean of NT and NC over the four selected news outlets to be useful.

NT is coded as positive (1), neutral (0), or negative (-1). Only predominantly judgmental statements or descriptions of actors or situations by journalists, concerned parties, adversaries, or independent actors such as politicians, business people or scientists lead to positive or negative NT coding. NT is coded as positive when explicitly positive terms are mentioned, such as good, excellent, or promising or the topic is embedded in an implicitly positive context, such 
as decreasing unemployment figures or company profits. If no predominant positive or negative tendencies are identifiable, the article or report is coded as neutral. The means of NT and NC are -.18 and $.56(-.28$ and .48$)$ for the news on the general economy (employment) over the observed 114 months, revealing a slightly negative level with rather strong deviations.

The coding of economic news is carried out on original print copy and broadcasts by professionally trained, full-time coders at Media Tenor. Every coder must pass a validity test with a minimum score of $87 \%$ before analyzing media content. Intercoder reliability is continuously tested with Krippendorff's alpha, at the level of the article or report (i.e., main topic), reference objects (e.g., companies), and the statement. At every level, intercoder reliability is maintained at a minimum of $87 \% .{ }^{65}$ Media Tenor data are often used in academic research. ${ }^{66}$

Economic Indicators. We use the industrial production index and the unemployment rate from the German Federal Statistical Office as economic indicators (EI). The industrial production index is available monthly, whereas the GDP is available only quarterly. Yet industrial production is closely related to the GDP in Germany. Therefore, the industrial production index can be considered as indicating the general state of the economy and has been widely used in monthly analyses. ${ }^{67}$ On average, $8.9 \%$ of the German population had personal experience of unemployment within the observation period with a maximum of $11.5 \%$ in 2005 . After the severe 2008/9 recession, the unemployment rate tops $8 \%$ in mid-2009. Both real-world indicators are seasonally adjusted. The industrial production index is also working-day adjusted. 
Public Expectations. Public expectations (PE) concerning the general state of the economy and unemployment expectations are obtained from the monthly consumer survey of the European Commission. This survey has been conducted in the European Union Member States and candidate countries by partner institutes on behalf of the European Commission according to a commonly agreed methodology since $1961 .{ }^{68}$ The consumer survey is comparable to the University of Michigan Consumer Sentiment Survey for the United States. For this survey, 2,000 respondents among the German population older than 14 years are polled through inhome, computer-assisted face-to-face interviews during the first two weeks of every month. Sampling is stratified by gender, age, occupation, household size, federal region, and community size. The sampling error has a confidence level of $95 \%$ and the error for a $10 \%$ share is $+-1.3 \%{ }^{69}$ The question used to determine public opinion on the expected development of the general state of the economy is, "How do you expect the general economic situation in this country to develop over the next 12 months?"70 The question used to determine public opinion on unemployment expectations is, "How do you expect the number of people unemployed in this country to change over the next 12 months?"71 The answers are given on a fivepoint ordinal scale (and a don't know category $(\mathrm{N})$ ): The economic situation will..."get a lot better" (PP), "get a little better" (P), "stay the same," (E) "get a little worse" (M) or "get a lot worse" (MM); employment will..."increase sharply" (PP), "increase slightly" (P), "remain the same," (E) "fall slightly" (M) or "fall sharply" (MM). On the basis of the distribution of the answer options for each question, the European Commission calculates balances (B) ranging from -100 to +100 on the basis of weighted averages as $B=(P P+1 / 2 P)-(1 / 2 M+M M)$ where PP $+\mathrm{P}+\mathrm{E}+\mathrm{M}+\mathrm{MM}+\mathrm{N}=100(\mathrm{~N}$ is the percentage of respondents without any opinion). The 
balances are seasonally adjusted. Hence, the public expectation indicators are a measure of the average and the frequency of opinions.

Figures 1 and 2 plot EI, PE, NT, NC, and NV, for the general economy and for employment respectively, against time. For equivalent display and analysis, all data standardized by ztransforming are therefore mean-centered to zero.

Figure 1: Production index, news on the general state of the economy, and public expectations for the general state of the economy

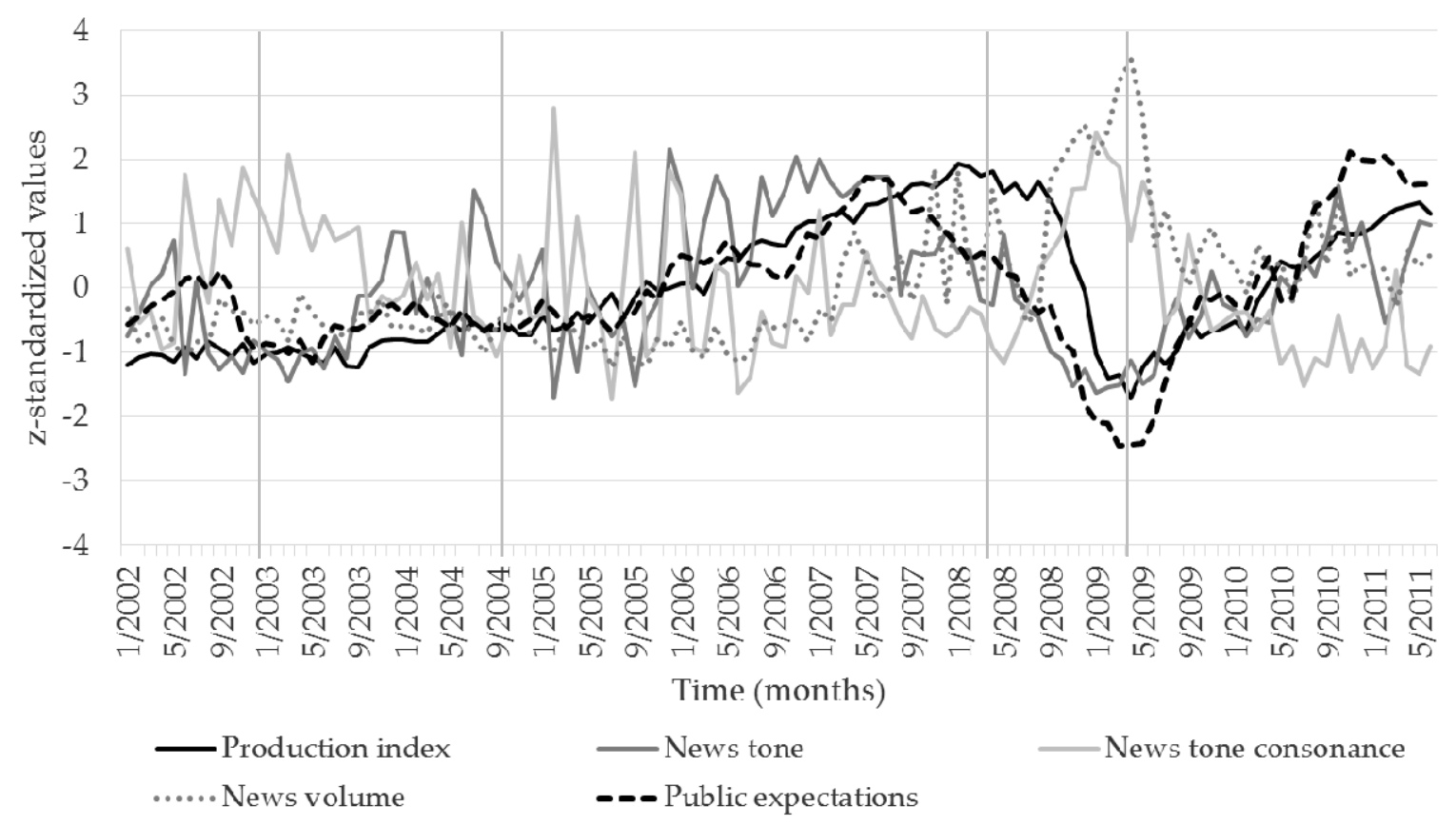

Note. All data are z-transformed. The recession periods (Q1 2003 to Q3 2004; Q2 2008 to Q1 2009) are marked. NT, NC, and NC of news on the general economic situation are displayed $(\mathrm{N}=4,152)$. Public expectations refer to the question "How do you expect the general economic situation in this country to develop over the next 12 months?" 
Figure 2: Unemployment rate, news on employment and public expectations for unemployment

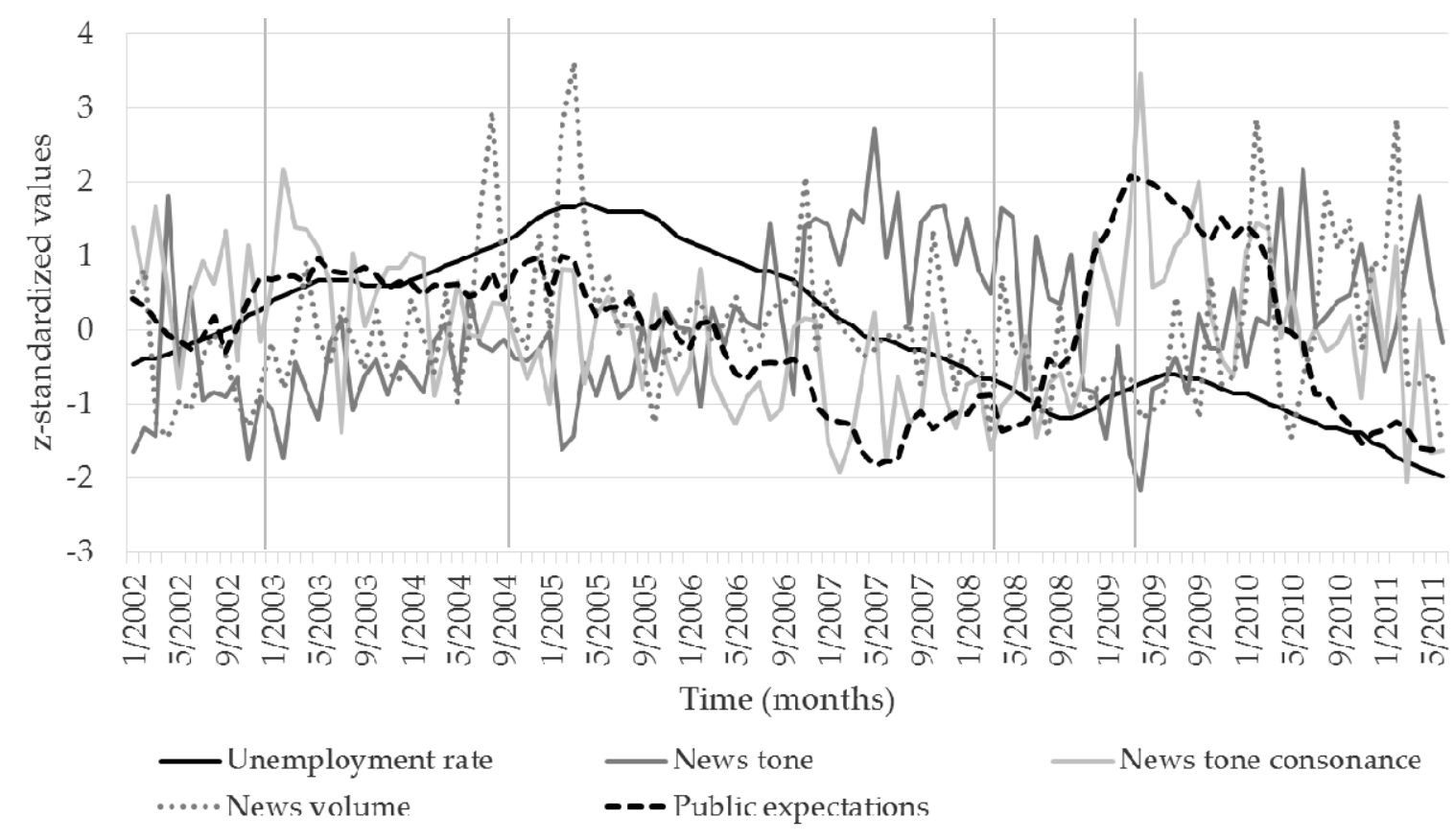

Note. All data are z-transformed. The recession periods (Q1 2003 to Q3 2004; Q2 2008 to Q1 2009) are marked. NT, NC, and NV of news on employment are displayed $(\mathrm{N}=4,806)$. Public expectations refer to the question "How do you expect the number of people unemployed in this country to change over the next 12 months?"

Measurement. The temporal relation between economic indicators, news coverage, and public expectations is estimated using VAR modeling ${ }^{72}$ and Granger causality. ${ }^{73}$ The VAR approach is to write a symmetrical system of equations that allows dynamic and interdependent analyses between the variables of interest. ${ }^{74} \mathrm{~A}$ VAR model including the past of the dependent and independent variables of the form

$$
\begin{aligned}
& \text { (1a) } \Delta Y_{t}=\alpha_{1}+\beta_{1} \Delta Y_{t-n}+\lambda_{1} \Delta X_{t-n}+\varepsilon_{1 t} \\
& \text { (1b) } \Delta X_{t}=\alpha_{2}+\lambda_{2} \Delta X_{t-n}+\beta_{2} \Delta Y_{t-n}+\varepsilon_{2 t}
\end{aligned}
$$

is applied to the data, where $\alpha$ is the constant, $\beta_{1}$ and $\lambda_{2}$ are the autoregressive coefficients of the dependent variable, $\lambda_{1}$ and $\beta_{2}$ are the coefficients of the independent variable, and $\varepsilon$ is the error term. With VAR models, a variable is described as a result of its own past and that of 
other variables. Granger causality is based on VAR models and tests whether a variable can be better predicted by using the past (lags) of another variable instead of just its own. This concept is therefore not causal but explores lead-lag relations or forecasting qualities. After each VAR model is estimated, Granger causality tests are used to determine whether $X_{t-n}$ helps forecasting $Y_{t}(1 \mathrm{a})$. In addition, the sign (+/-) of the VAR coefficients reveals whether the relation is positive or negative. This VAR procedure follows recent research on the relations between the "reality", media content, and public opinion. ${ }^{75}$

In time series modeling it is crucial that the data fulfill the condition of (weak) stationarity to avoid spurious correlations, a low Durbin-Watson d-statistic revealing autocorrelated residuals, a high $R^{2}$, and high significance of the coefficients. ${ }^{76}$ The commonly used augmented Dickey-Fuller (ADF) test is performed to detect the unit roots and the Kwiatkowski-PhillipsSchmidt-Shin (KPSS) test is used to assess trends and level stationarity for each time series. The variables, public opinion and economic indicators, contain trends and drifts, especially around 2009 during the financial crisis (see Figures 1-2) and are non-stationary. NT, NC, and $\mathrm{NC}$ are stationary according to ADF and KPSS. ${ }^{77}$ To eliminate the trend from the non-stationary series and achieve mean stationarity, the common method used is differencing. ${ }^{78}$ Differentiated time series of order one $\left(Y_{t}-Y_{t-1}, \Delta\right)$ for PE and EI are tested as stationary according to ADF and KPSS tests. Therefore, the analysis is executed based on changes $(\Delta)$ in the current month $(t)$ compared with the previous month (t-1) for PE and EI and based on levels in the current month $(t)$ for NT, NC, and NV. This approach is similar to that of Soroka's media content time series. ${ }^{79}$ For the interaction terms, products of non-standardized data are calcu- 
lated and afterwards z-transformed. For NTxNC (PExNC), a higher consonance should reinforce and a lower consonance should weaken NT (PE) values. Therefore, NC is computed as $(1+$ mean $(\operatorname{stdevNT}))-$ stdevNT so that the new mean of NC is 1. For PExNT (EIxNT), negative PE (EI) and negative NT inverts PE (EI) to in positive interaction values whereas positive NT weakens negative PE (EI).

The appropriate lag order of the model is selected by using Akaike's information criterion and Wald lag exclusion statistics. All VAR models satisfy the Eigenvalue stability condition. For testing separate effects of the recession periods $2003 / 4$ and $2008 / 9$, the variables are set to zero (mean) during the remaining periods. This procedure allows the analysis of the complete observation period without break while absorbing (non-)recession effects. Since the autocorrelation or a non-white noise process of the residuals $\varepsilon^{\wedge}$ can lead to misinterpretation of the relation between variables, Durbin-Watson and Portmanteau tests are performed.

\section{Findings}

Impact of Economic Indicators and Public Expectations on News Coverage. For RQ1, we ask whether real-world EI or PE better forecast news coverage (NT, NC, NV) in recessions or non-recession periods. Table 1 shows that NT of news on the general economy is barely set by the corresponding EI or PE but depends strongly on NT of the previous month (column 1, t$\left.1+^{* * *}\right)$. The negative signs of the EI coefficients reveal that the more positive the economic development is, the less consonant is NT and vice versa (column 2). The more negative PE was two months ago (column $\left.3, t-2-^{* *}, \mathrm{t}-2-^{*}\right)$, the more NV is published now. NT and NC of news on employment strongly depend on past unemployment numbers. The more unemploy- 
ment there is, the more negative and consonant is NT (column 4). With decreasing unemployment, NT also becomes less consonant, as the positive signs of the EI coefficients reveal (column 5). During the 2008/9 recession, negative PE forecast a more positive NT indicating that PE and NT were not in alignment (column 6). Yet NV can be forecast neither by unemployment numbers nor by corresponding PE but by the NV on the general economy (column 7): The more news there is on the general economy, the less employment news there is in the subsequent month $\left(t-1-^{* *}\right)$. The unemployment news tends to be caught up one month later $\left(t-2+^{\circ}\right)$. Hence, journalistic interpretation $(N T, N C)$ depends more on EI than on PE. Only journalistic selection (NV) of news on the general economy is partly related to previous changes in PE.

Impact of News Coverage and Economic Indicators on Public Expectations. Table 2 shows results for public expectations being the dependent variable. Variables and interaction terms are added to the models step by step. As indicated by Granger causality and the level of significance of the coefficients, EI on the general state of the economy can better forecast PE for the general economy $(\mathrm{H} 1)$ and even better on unemployment $(\mathrm{H} 2)$ than can NT, NC, or NV for the total observation period (models 1 and $1^{\prime}$ ). When the production index increases, PE for the general economy will become more optimistic $\left(t-3+^{*}\right)$, and a decrease in unemployment is expected $\left(t-1-^{* *}, t-3-^{*}\right)$. Yet changes in real-world unemployment numbers cannot forecast public unemployment expectations (models 1 and 2). Therefore, we accept $\mathrm{H} 1$ in part and $\mathrm{H} 2$ in full.

The interaction effect between NT and NC shows a negative sign of the coefficient for PE for the general economy (model 2). Hence, the less consonant it is, the more NT tends to affect PE 
for the general economy. However, this interaction effect is not significant for unemployment expectations. Therefore, we do not accept H3.

We also find no support for $\mathrm{H} 4$ stating that the higher the unemployment numbers, the smaller the effect of news on PE. But NT effects tend to increase with higher unemployment numbers (unemployment, model 2, row NTxEI, $t-2+^{\circ}$, ). This effect is not significant in other models.

Model 3 relates to H5 and reveals that EI of three months ago tends to forecast PE on the general economy in non-recession times whereas NT of the previous month tends to forecast PE in the 2008/9 recession. This NT effect increases with higher NV (model $4, t-1+^{* *}$ ). Unemployment numbers positively forecast and Granger cause public unemployment expectations in non-recession times and the weaker 2003/4 recession (model 3). Employment NT can forecast PE on national unemployment in all periods-but the more negative the NT, the less unemployment the public expects. Also the tone of news on the general economy (model 3") cannot forecast the public unemployment expectations in the expected direction in the 2003/4 recession $\left(t-3+^{*}\right)$ but can do so to some degree in the 2008/9 recession $\left(t-1-^{*}\right)$.To sum up, PE were not set by EI during the severe 2008/9 recession. Only NT for the general economy of the previous month can forecast both PE for the general economy and for unemployment during the 2008/9 recession in the expected direction. Therefore, we accept $\mathrm{H} 5$ in part.

The role of NV is tested directly in model 1 for the general economy and unemployment, revealing that more news leads to more optimistic PE for the economy and the expectation of a decrease in unemployment numbers. The interaction effect of NT and NV reveals that the 
NT effect on the PE for the general economy tends to increase with higher volume (models 2 and 4 , row NTxNV $\left., t-1+^{*}, t-1+^{* *}\right)$.

Concerning the quality of the models, PE models for the general economy fit better according to the $F$ value and Portmanteau test. An explained variance (adjusted $R^{2}$ ) up to $30 \%$ can be reached when including interaction terms. However, it is not sufficient to explain national unemployment expectations with unemployment numbers or the production index and unemployment news or news on the general economy as adjusted $R^{2}$ remains low.

Impact of News Coverage and Public Expectations on Economic Indicators. The results in Table 3, model 1, reveal that PE on the general economy positively forecast the production index. According to the sign of the PE coefficient, more optimistic PE one month earlier Granger causes an increase in the production index now $\left(t-1+^{* *}\left(3.842^{* * *}\right)\right)$. Therefore, we accept H6. In contrast, unemployment expectations are not found to have the capacity to forecast employment numbers.

News coverage has no direct unconditional effect on the production index in model 1. To add interaction terms between PE and news coverage improves the model quality (model 2). Interaction terms reveal that the forecasting ability of PE for the production index tends to decrease with less consonant NT $\left(t-3-^{\circ}\right)$ and less NV $\left(t-2-^{*}\right)$. When public expectations are on average lower, NC tends to forecast a more positive economic development in the next quarter $\left(\mathrm{t}-3-^{\circ}\right)$. Hence, news coverage is not positively related to the production index. Therefore, we reject $\mathrm{H7}$. 


\section{Discussion}

This study compares economic news coverage by major German news outlets with real economic indicators and public economic expectations. First, the interpretation of economic news is mainly set by changes in economic indicators and rarely by public expectations confirming previous research. ${ }^{80}$ A more negative economic development tends to lead to a more negative and more consonant NT. By the same token, the more positive the economic development, the less consonant the NT. The fewer unemployed people there are, the more positive is employment news - but the less consonant it is, as well. That is, news interpretation is more consistent in downturns and less consistent in upturns - which may be caused by asymmetric responses to negative events by journalists. ${ }^{81}$ Economic indicators are not explicitly stronger drivers of news during recessions, but public expectations are. NV concerning the general economy was clearly forecast by public expectations for the economy during the 2008/9 recession. Hence, general economic NV did not respond in a "fire alarm" fashion to warn the public, ${ }^{82}$ but public opinion did herald increased NV. The increase of news on the general economy leads to a decrease in the unemployment NV. In line with Soroka ${ }^{83}$ we argue that a certain amount of noise and the salience of the issue of the general economy produce this result. Also, the development of news coverage is much more volatile than the development of realworld economic indicators and public expectations, indicating that journalistic selection and interpretations are versatile and voluminous and do not represent solely the economic development on aggregate level. 
Second, public economic expectations are more influenced by economic indicators than by news coverage supporting the obtrusive contingency hypothesis. Yet the effects of NT increase with greater NV instead of NC. In the 2008/9 recession, NT concerning the general economy positively forecast public expectations for the general economy and, more clearly, unemployment expectations. This is in line with findings revealing stronger agenda-setting effects during recessions ${ }^{84}$ or for negative news..$^{85}$ The public concludes that unemployment increases as a result of a declining general economic situation. An increase in employment $\mathrm{NV}$ also forecasts more pessimistic unemployment expectations. This relates to the results of Golan and Wanta, ${ }^{86}$ who show that news volume is a stronger predictor of public opinion than tone.

Public expectations for the general economy are explained by the corresponding economic indicator and news coverage. During stable economic times and the less severe 2003/4 recession, decreasing unemployment numbers and an improving general state of the economy forecast a decrease in national unemployment expectations. A previous study that fails to reveal short-term agenda-setting effects for unemployment in Sweden explains that the lack of agenda setting is due to constant high news coverage over the years. ${ }^{87}$ This situation-in which the public may be oversaturated with news on unemployment-may prevent news from having an effect on the public's unemployment expectations even in the present study. If unemployment is regarded as a more obtrusive topic than the general economy, a lack of agenda-setting effects can be explained according to the obtrusive contingency hypothesis. However, this study suggests another explanation. Unemployment expectations are devel- 
oped based on preceding economic indicators and news such as on the general economy. Another explanation lies in the inability of aggregate data analysis to link public opinion with media usage on a micro level of the individual. Although collective media effects can be expected and the selected news outlets are the most popular in Germany and news media are found to be the most important information sources for audiences on the general state of the economy, ${ }^{88}$ not all economic actors receive economic news with the same frequency, nor do they receive the same economic news.

Third, as expected, public expectations for the general economy forecast the real-world economic development whereas news does not have an unconditional direct effect. This result supports the finding of $\mathrm{Wu}$ et al., ${ }^{89}$ revealing that public expectations forecast economic performance. Two explanations are possible for this forecasting ability. Either, the public makes correct assumptions about developments in the economy. Or, the public influences the economy via economic decision making. The latter would support the concept of expectationdriven business cycles explaining changes in the economy through changes in economic expectations. However, the influence of public opinion on a change in the production index is very short term - only one month in the present study. Unemployment expectations are not found to have the capacity to forecast employment numbers. Because the employment situation is experienced by the population directly and is a result of the state of the economy, since it is a lagging indicator, ${ }^{90}$ public expectations may not influence employment numbers, since the employment situation cannot be changed by media coverage or attitudinal or behavioral changes in the audience but is, instead, a result of the state of the economy. Further research 
could include actual decision making of the public, such as consumption decisions, to clarify whether the public correctly anticipates or influences economic development.

In conclusion, first, economic news are a result of the interpretation of noisy real-world developments. Journalistic interpretation on economic issues is related to but goes beyond aggregate economic indicators. More narrow news issue selection or more specialized news outlets might reveal closer relations between news coverage and economic indicators. Second, people are more likely to use information gathered from their daily lives to develop economic sentiment than information gathered from the general news. High NV instead of NC is a condition for stronger NT effects. Hence, second-level agenda-setting effects depend on news quality and quantity. Third, public unemployment expectations also depend on news on the general economy. Therefore, the public correctly anticipates the unemployment development in the future. 
Table 1: Impact of economic indicators and public expectations on news coverage

\begin{tabular}{|c|c|c|c|c|c|c|c|}
\hline \multirow{4}{*}{$\begin{array}{l}\text { Dependent variable } \\
\text { Past NT/NC/NV }\end{array}$} & \multicolumn{7}{|c|}{ News coverage } \\
\hline & \multicolumn{3}{|c|}{$\begin{array}{l}\text { General situation of the } \\
\text { economy }\end{array}$} & \multicolumn{4}{|c|}{ Employment } \\
\hline & NT & $\mathrm{NC}$ & NV & NT & $\mathrm{NC}$ & NV & $\mathrm{NV}$ \\
\hline & $\begin{array}{c}t-1+^{* * *} \\
t-2+^{\circ}\end{array}$ & $t-1+^{* *}$ & $\begin{array}{c}t-1+^{* * *}, \\
t-2+^{* *}\end{array}$ & $t-2+^{*}$ & $t-1+^{*}$ & $t-1+^{*}$ & $t-1+^{*}$ \\
\hline$\Delta$ EI 2003/04 & $\begin{array}{l}\text { n.s. }(-) \\
\left(2.532^{\circ}\right)\end{array}$ & $\begin{array}{l}t-2-^{\circ} \\
\text { (n.s.) }\end{array}$ & $\begin{array}{l}\text { n.s. } \\
\text { (n.s.) }\end{array}$ & $\begin{array}{c}t-1-^{\circ} \\
\left(5.340^{* *}\right)\end{array}$ & $\begin{array}{c}t-1+^{*} \\
\left(4.582^{*}\right)\end{array}$ & $\begin{array}{l}t-1+^{\circ} \\
\text { (n.s.) }\end{array}$ & $\begin{array}{l}\text { n.s. } \\
\text { (n.s.) }\end{array}$ \\
\hline$\Delta$ EI 2008/09 & $\begin{array}{l}\text { n.s. } \\
\text { (n.s.) }\end{array}$ & $\begin{array}{c}t-1-^{*}, t-2-^{*} \\
\left(4.617^{*}\right)\end{array}$ & $\begin{array}{l}\text { n.s. } \\
\text { (n.s.) }\end{array}$ & $\begin{array}{c}t-1-^{*} \\
\left(5.362^{* *}\right)\end{array}$ & $\begin{array}{c}t-1+^{*} \\
\left(4.446^{* *}\right)\end{array}$ & $\begin{array}{l}\text { n.s. } \\
\text { (n.s.) }\end{array}$ & $\begin{array}{l}\text { n.s. } \\
\text { (n.s.) }\end{array}$ \\
\hline$\Delta \mathrm{EI}$ no recession & $\begin{array}{l}t-1+^{\circ} \\
\text { (n.s.) }\end{array}$ & $\begin{array}{c}t-1-^{\circ}, t-2-^{\circ} \\
\left(3.757^{*}\right)\end{array}$ & $\begin{array}{l}\text { n.s. } \\
\text { (n.s.) }\end{array}$ & $\begin{array}{c}t-1-^{\circ} \\
\left(8.308^{* * *}\right)\end{array}$ & $\begin{array}{c}t-1+^{*} \\
\left(7.041^{* *}\right)\end{array}$ & $\begin{array}{l}\text { n.s. } \\
\text { (n.s.) }\end{array}$ & $\begin{array}{l}\text { n.s. } \\
\text { (n.s.) }\end{array}$ \\
\hline$\triangle$ PE 2003/04 & $\begin{array}{l}t-1+^{*} \\
\text { (n.s.) }\end{array}$ & $\begin{array}{l}\text { n.s. } \\
\text { (n.s.) }\end{array}$ & $\begin{array}{l}\text { n.s. } \\
\text { (n.s.) }\end{array}$ & $\begin{array}{l}\text { n.s. } \\
\text { (n.s.) }\end{array}$ & $\begin{array}{l}\text { n.s. } \\
\text { (n.s.) }\end{array}$ & $\begin{array}{l}\text { n.s. } \\
\text { (n.s.) }\end{array}$ & $\begin{array}{l}\text { n.s. } \\
\text { (n.s.) }\end{array}$ \\
\hline$\triangle$ PE 2008/09 & $\begin{array}{l}\text { n.s. } \\
\text { (n.s.) }\end{array}$ & $\begin{array}{l}\text { n.s. } \\
\text { (n.s.) }\end{array}$ & $\begin{array}{l}t-2^{* *} \\
\left(3.492^{*}\right)\end{array}$ & $\begin{array}{c}t-1-^{*} \\
\left(2.80^{\circ}\right)\end{array}$ & $\begin{array}{l}\text { n.s. } \\
\text { (n.s.) }\end{array}$ & $\begin{array}{l}\text { n.s. } \\
\text { (n.s.) }\end{array}$ & $\begin{array}{l}\text { n.s. } \\
\text { (n.s.) }\end{array}$ \\
\hline$\Delta \mathrm{PE}$ no recession & $\begin{array}{l}\text { n.s. } \\
\text { (n.s.) }\end{array}$ & $\begin{array}{l}\text { n.s. } \\
\text { (n.s.) }\end{array}$ & $\begin{array}{c}t-2-^{*} \\
\left(2.171^{\circ}\right)\end{array}$ & $\begin{array}{l}\text { n.s. } \\
\text { (n.s.) }\end{array}$ & $\begin{array}{l}\text { n.s. } \\
\text { (n.s.) }\end{array}$ & $\begin{array}{l}\text { n.s. } \\
\text { (n.s.) }\end{array}$ & $\begin{array}{l}\text { n.s. } \\
\text { (n.s.) }\end{array}$ \\
\hline $\begin{array}{l}\mathrm{NV} \text { on the general } \\
\text { economy }\end{array}$ & & & & & & & $\begin{array}{c}t-1-^{* *} \\
t-2+^{\circ} \\
\left(4.712^{*}\right)\end{array}$ \\
\hline Constant & -0.008 & 0.045 & 0.012 & -0.037 & 0.031 & 0.010 & 0.010 \\
\hline Lag structure & $t-1, t-2$ & $t-1, t-2$ & $\begin{array}{c}t-1, t-2 \\
t-3\end{array}$ & $t-1, t-2$ & $t-1, t-2$ & $t-1, t-2$ & $t-1, t-2$ \\
\hline $\mathrm{n}$ & 111 & 111 & 110 & 111 & 111 & 111 & 111 \\
\hline Adjusted $R^{2}$ & 0.546 & 0.262 & 0.715 & 0.425 & 0.298 & 0.108 & 0.172 \\
\hline$F$ & $10.266^{* * *}$ & $3.672^{* * *}$ & $13.793^{* * *}$ & $6.674^{* * *}$ & $4.227^{* * *}$ & $1.859^{*}$ & $2.341^{* *}$ \\
\hline RMSE & 0.684 & 0.872 & 0.543 & 0.749 & 0.834 & 0.952 & 0.917 \\
\hline $\begin{array}{l}\text { Durbin-Watson } d- \\
\text { statistic }\end{array}$ & 2.081 & 2.079 & 2.088 & 1.863 & 2.006 & 1.962 & 2.018 \\
\hline $\begin{array}{l}\text { Portmanteau test for } \\
\text { white noise }(Q)\end{array}$ & 30.927 & 35.916 & 41.733 & 43.497 & 33.642 & 26.736 & 29.347 \\
\hline
\end{tabular}

Note. $\Delta$ : first differences, otherwise levels. Cells contain the lags and signs of significant VAR coefficients with Granger causality $F$ value in parentheses. For Granger causality, the null hypotheses that the coefficients on all the lags of an endogenous variable are jointly zero is tested. n.s.: not significant, ${ }^{\circ}$ : significant on $10 \%$ level, ${ }^{*}$ : significant on $5 \%$ level, ${ }^{* *}$ : significant on $1 \%$ level, ${ }^{* * *}$ : significant on $.1 \%$ level. EI for general economy is the production index, EI number for employment is the unemployment rate, PE question for the general economy: "How do you expect the general economic situation in this country to develop over the next 12 months?," PE question for employment: "How do you expect the number of people unemployed in this country to change over the next 12 months?" 
Table 2: Impact of economic indicators and news coverage on the public expectations for the general economy and national unemployment

\begin{tabular}{|c|c|c|c|c|c|c|c|c|c|c|c|}
\hline Dependent variable & \multicolumn{4}{|c|}{$\begin{array}{l}\text { Public expectations (PE) on the general } \\
\text { economy }\end{array}$} & \multicolumn{7}{|c|}{ Public expectations (PE) on national unemployment } \\
\hline Model & 1 & 2 & 3 & 4 & 1 & $1^{\prime}$ & 2 & 3 & 3" & 4 & 4" \\
\hline$\triangle$ Past PE & $t-1+^{\circ}$ & $t-3+^{\circ}$ & $t-1+^{\circ}$ & $t-1+^{*}$ & $t-3+^{\circ}$ & n.s. & n.s. & $t-3+^{*}$ & $t-2-^{\circ}$ & n.s. & n.s. \\
\hline$\Delta$ EI 2002-11 & $\begin{array}{c}t-3+^{*} \\
\left(2.942^{\circ}\right)\end{array}$ & $t-3+*$ & & & $\begin{array}{l}\text { n.s. } \\
\text { (n.s.) }\end{array}$ & $\begin{array}{c}t-1-^{* *} \\
t-3-^{*} \\
\left(4.400^{* *}\right)\end{array}$ & $\begin{array}{l}\text { n.s. } \\
\text { (n.s.) }\end{array}$ & & & & \\
\hline$\Delta$ EI 2003/04 & & & $\begin{array}{l}\text { n.s. } \\
\text { (n.s.) }\end{array}$ & $\begin{array}{l}\text { n.s. } \\
\text { (n.s.) }\end{array}$ & & & & $\begin{array}{c}t-1+^{\circ} \\
\left(3.142^{*}\right)\end{array}$ & $\begin{array}{c}t-1-^{*}, \\
t-3-^{\circ} \\
\left(2.169^{\circ}\right)\end{array}$ & $\begin{array}{c}t-2+^{\circ} \\
\left(3.414^{*}\right)\end{array}$ & $\begin{array}{l}\text { n.s. } \\
\text { (n.s.) }\end{array}$ \\
\hline$\Delta$ EI 2008/09 & & & $\begin{array}{l}\text { n.s. } \\
\text { (n.s.) }\end{array}$ & $\begin{array}{l}\text { n.s. } \\
\text { (n.s.) }\end{array}$ & & & & $\begin{array}{l}\text { n.s. } \\
\text { (n.s.) }\end{array}$ & $\begin{array}{l}t-1-^{*} \\
\text { (n.s.) }\end{array}$ & $\begin{array}{l}t-2+^{\circ} \\
\text { (n.s.) }\end{array}$ & $\begin{array}{l}\text { n.s. } \\
\text { (n.s.) }\end{array}$ \\
\hline$\Delta$ EI no recession & & & $\begin{array}{l}t-3+^{\circ} \\
(\text { n.s. })\end{array}$ & $\begin{array}{c}t-3+^{*} \\
\left(2.170^{\circ}\right)\end{array}$ & & & & $\begin{array}{c}t-1+^{\circ} \\
\left(3.338^{*}\right)\end{array}$ & $\begin{array}{c}t-1-^{*} \\
t-3-^{\circ} \\
\left(2.708^{*}\right)\end{array}$ & $\begin{array}{c}t-2+^{\circ} \\
\left(3.424^{*}\right)\end{array}$ & $\begin{array}{l}t-1-^{\circ} \\
\text { (n.s.) }\end{array}$ \\
\hline NT 2002-11 & $\begin{array}{c}t-1+^{\circ}, t-3-^{\circ} \\
\text { (n.s.) }\end{array}$ & $\begin{array}{l}\text { n.s. } \\
\text { (n.s.) }\end{array}$ & & & $\begin{array}{l}\text { n.s. } \\
\text { (n.s.) }\end{array}$ & $\begin{array}{l}\text { n.s. } \\
\text { (n.s.) }\end{array}$ & $\begin{array}{l}\text { n.s. } \\
\text { (n.s.) }\end{array}$ & & & & \\
\hline NT 2003/04 & & & $\begin{array}{l}\text { n.s. } \\
\text { (n.s.) }\end{array}$ & $\begin{array}{l}\text { n.s. } \\
\text { (n.s.) }\end{array}$ & & & & $\begin{array}{l}t-2+^{*} \\
\text { (n.s.) }\end{array}$ & $\begin{array}{l}t-3+^{*} \\
\text { (n.s.) }\end{array}$ & $\begin{array}{l}\text { n.s. } \\
\text { (n.s.) }\end{array}$ & $\begin{array}{l}\text { n.s. } \\
\text { (n.s.) }\end{array}$ \\
\hline NT 2008/09 & & & $\begin{array}{l}t-1+^{\circ} \\
\text { (n.s.) }\end{array}$ & $\begin{array}{l}\text { n.s. } \\
\text { (n.s.) }\end{array}$ & & & & $\begin{array}{l}t-3+^{*} \\
\text { (n.s.) }\end{array}$ & $\begin{array}{l}t-1-^{*}, \\
t-3+^{\circ} \\
\text { (n.s.) }\end{array}$ & $\begin{array}{l}\text { n.s. } \\
\text { (n.s.) }\end{array}$ & $\begin{array}{l}\text { n.s. } \\
\text { (n.s.) }\end{array}$ \\
\hline NT no recession & & & $\begin{array}{l}\text { n.s. } \\
\text { (n.s.) }\end{array}$ & $\begin{array}{l}\text { n.s. } \\
\text { (n.s.) }\end{array}$ & & & & $\begin{array}{c}t-2+^{*} \\
\left(2.097^{\circ}\right)\end{array}$ & $\begin{array}{l}\text { n.s. } \\
\text { (n.s.) }\end{array}$ & $\begin{array}{l}\text { n.s. } \\
\text { (n.s.) }\end{array}$ & $\begin{array}{l}\text { n.s. } \\
\text { (n.s.) }\end{array}$ \\
\hline NC 2002-11 & $\begin{array}{l}t-3-^{\circ} \\
\text { (n.s.) }\end{array}$ & $\begin{array}{c}\text { n.s. } \\
\text { (n.s.) }\end{array}$ & & $\begin{array}{l}\text { n.s. } \\
\text { (n.s.) }\end{array}$ & $\begin{array}{l}\text { n.s. } \\
\text { (n.s.) }\end{array}$ & $\begin{array}{c}\text { n.s. } \\
\text { (n.s.) }\end{array}$ & $\begin{array}{c}\text { n.s. } \\
\text { (n.s.) }\end{array}$ & & & $\begin{array}{l}\text { n.s. } \\
\text { (n.s.) }\end{array}$ & $\begin{array}{l}t-2-^{\circ} \\
\text { (n.s.) }\end{array}$ \\
\hline
\end{tabular}




\begin{tabular}{|c|c|c|c|c|c|c|c|c|c|c|c|}
\hline NV 2002-11 & $\begin{array}{l}t-3+^{*} \\
\text { (n.s.) }\end{array}$ & $\begin{array}{l}\text { n.s. } \\
\text { (n.s.) }\end{array}$ & & $\begin{array}{l}\text { n.s. } \\
\text { (n.s.) }\end{array}$ & $\begin{array}{c}t-1-^{*} \\
\left(2.680^{\circ}\right)\end{array}$ & $\begin{array}{c}t-1-^{*} \\
\left(2.169^{\circ}\right)\end{array}$ & $\begin{array}{l}t-1-^{\circ} \\
\text { (n.s.) }\end{array}$ & & & $\begin{array}{l}\text { n.s. } \\
\text { (n.s.) }\end{array}$ & $\begin{array}{l}\text { n.s. } \\
\text { (n.s.) }\end{array}$ \\
\hline NTxNC 2002-11 & & $\begin{array}{l}t-3-^{\circ} \\
\text { (n.s.) }\end{array}$ & & $\begin{array}{l}\text { n.s. } \\
\text { (n.s.) }\end{array}$ & & & $\begin{array}{l}\text { n.s. } \\
\text { (n.s.) }\end{array}$ & & & $\begin{array}{l}\text { n.s. } \\
\text { (n.s.) }\end{array}$ & $\begin{array}{l}\text { n.s. } \\
\text { (n.s.) }\end{array}$ \\
\hline NTxNV 2002-11 & & $\begin{array}{c}t-1+^{*} \\
\left(2.828^{\circ}\right)\end{array}$ & & $\begin{array}{c}t-1+^{* *}, \\
t-2-^{\circ} \\
\left(5.172^{* *}\right)\end{array}$ & & & $\begin{array}{l}\text { n.s. } \\
\text { (n.s.) }\end{array}$ & & & $\begin{array}{l}\text { n.s. } \\
\text { (n.s.) }\end{array}$ & $\begin{array}{l}\text { n.s. } \\
\text { (n.s.) }\end{array}$ \\
\hline NTxEI 2002-11 & & $\begin{array}{c}\text { n.s. } \\
\text { (n.s.) }\end{array}$ & & $\begin{array}{c}\text { n.s. } \\
\text { (n.s.) }\end{array}$ & & & $\begin{array}{l}t-2+^{\circ} \\
\text { (n.s.) }\end{array}$ & & & $\begin{array}{l}\text { n.s. } \\
\text { (n.s.) }\end{array}$ & $\begin{array}{l}\text { n.s. } \\
\text { (n.s.) }\end{array}$ \\
\hline Constant & 0.001 & 0.004 & -0.001 & -0.038 & 0.005 & 0.002 & 0.008 & 0.017 & -0.008 & 0.013 & -0.001 \\
\hline Lag structure & $t-1, t-3$ & $t-1, t-3$ & $\begin{array}{c}t-1, t-2, t- \\
3\end{array}$ & $\begin{array}{c}t-1, t-2 \\
t-3\end{array}$ & $\begin{array}{c}t-1, t-2, \\
t-3\end{array}$ & $\begin{array}{c}t-1, t-2 \\
t-3\end{array}$ & $\begin{array}{c}t-1, t-2 \\
t-3\end{array}$ & $\begin{array}{c}t-1, t-2, t- \\
3\end{array}$ & $\begin{array}{c}t-1, t-2, t- \\
3\end{array}$ & $\begin{array}{c}t-1, t-2 \\
t-3\end{array}$ & $\begin{array}{c}t-1, t-2 \\
t-3\end{array}$ \\
\hline $\mathrm{n}$ & 110 & 110 & 110 & 110 & 110 & 110 & 110 & 110 & 110 & 110 & 110 \\
\hline Adjusted $R^{2}$ & 0.194 & 0.312 & 0.098 & 0.238 & 0.132 & 0.194 & 0.176 & 0.153 & 0.170 & 0.139 & 0.092 \\
\hline$F$ & $3.480^{* * *}$ & $3.815^{* * *}$ & $1.500^{\circ}$ & $1.891^{*}$ & $2.017^{*}$ & $2.650^{* *}$ & $1.871^{*}$ & $1.873^{*}$ & $1.993^{*}$ & $1.440^{\circ}$ & 1.263 \\
\hline RMSE & 0.249 & 0.230 & 0.264 & 0.243 & 0.251 & 0.242 & 0.245 & 0.248 & 0.245 & 0.250 & 0.257 \\
\hline $\begin{array}{l}\text { Durbin-Watson } d- \\
\text { statistic } \\
\text { Portmanteau test for } \\
\text { white noise }(Q)\end{array}$ & 41.492 & 2.020 & 2.051 & 2.117 & $59.059^{*}$ & $75.857^{* * *}$ & 2.137 & 2.128 & $64.684^{* *}$ & 2.098 & $89.311^{* * *}$ \\
\hline
\end{tabular}

Note. ': EI = real-world economic indicator production index. ": EI = real-world economic indicator production index and NT, NC, NV = news on the general economy, $\Delta$ : first differences, otherwise levels. Cells contain the lags and signs of significant VAR coefficients with Granger causality $F$ value in parentheses. For Granger causality, the null hypothesis that the coefficients on all the lags of an endogenous variable are jointly zero is tested. n.s.: not significant, ${ }^{\circ}$ : significant on $10 \%$ level, ${ }^{*}$ : significant on $5 \%$ level, ${ }^{* *}$ : significant on $1 \%$ level, ${ }^{* * *}$ : significant on $.1 \%$ level. PE question for the general economy: "How do you expect the general economic situation in this country to develop over the next 12 months?" PE question for employment: "How do you expect the number of people unemployed in this country to change over the next 12 months?" 
Table 3: Impact of news coverage and public expectations for economic indicators

\begin{tabular}{|c|c|c|c|c|}
\hline \multirow{3}{*}{$\begin{array}{c}\text { Dependent } \\
\text { variable } \\
\text { Model }\end{array}$} & \multicolumn{4}{|c|}{ Economic indicator (EI) } \\
\hline & \multicolumn{2}{|c|}{ Production index } & \multicolumn{2}{|c|}{ Unemployment rate } \\
\hline & 1 & 2 & 1 & 2 \\
\hline$\Delta$ Past EI & $t-3+^{\circ}$ & n.s. & $t-1+^{* * *}, t-2+^{* *}$ & $t-1+^{* * *}, t-2+^{*}$ \\
\hline$\triangle$ PE 2001-11 & $t-1+^{* *}$ & n.s. & $t-1+^{\circ}$ & $t-1+^{*}$ \\
\hline & $\left(3.842^{*}\right)$ & (n.s.) & (n.s.) & (n.s.) \\
\hline NT 2002-11 & $\begin{array}{l}\text { n.s. } \\
\text { (n.s.) }\end{array}$ & $\begin{array}{l}\text { n.s. } \\
\text { (n.s.) }\end{array}$ & $\begin{array}{l}\text { n.s. } \\
\text { (n.s.) }\end{array}$ & $\begin{array}{l}\text { n.s. } \\
\text { (n.s.) }\end{array}$ \\
\hline NC 2002-11 & $\begin{array}{l}\text { n.s. } \\
\text { (n.s.) }\end{array}$ & $\begin{array}{l}t-3-^{\circ} \\
\text { (n.s.) }\end{array}$ & $\begin{array}{l}t-2-^{\circ} \\
\text { (n.s.) }\end{array}$ & $\begin{array}{l}\text { n.s. } \\
\text { (n.s.) }\end{array}$ \\
\hline NV 2002-11 & $\begin{array}{l}\text { n.s. } \\
\text { (n.s.) }\end{array}$ & $\begin{array}{l}\text { n.s. } \\
\text { (n.s.) }\end{array}$ & $\begin{array}{l}\text { n.s. } \\
\text { (n.s.) }\end{array}$ & $\begin{array}{l}\text { n.s. } \\
\text { (n.s.) }\end{array}$ \\
\hline PExNT 2002-11 & & $\begin{array}{l}\text { n.s. } \\
\text { (n.s.) }\end{array}$ & & $\begin{array}{l}t-3+^{\circ} \\
\text { (n.s.) }\end{array}$ \\
\hline PExNC 2002-11 & & $\begin{array}{l}t-3-^{\circ} \\
\text { (n.s.) }\end{array}$ & & $\begin{array}{l}\text { n.s. } \\
\text { (n.s.) }\end{array}$ \\
\hline PExNV 2002-11 & & $\begin{array}{l}t-2-^{*} \\
\text { (n.s.) }\end{array}$ & & $\begin{array}{l}\text { n.s. } \\
\text { (n.s.) }\end{array}$ \\
\hline Constant & 0.012 & 0.022 & -0.004 & -0.003 \\
\hline Lag structure & $t-1, t-2, t-3$ & $t-1, t-2, t-3$ & $t-1, t-2, t-3$ & $t-1, t-2, t-3$ \\
\hline $\mathrm{n}$ & 110 & 110 & 110 & 110 \\
\hline Adjusted $R^{2}$ & 0.136 & 0.203 & 0.651 & 0.651 \\
\hline$F$ & $2.060^{*}$ & $2.090^{* *}$ & $14.340^{* * *}$ & $9.325^{* * *}$ \\
\hline RMSE & 0.210 & 0.202 & 0.044 & 0.044 \\
\hline $\begin{array}{l}\text { Durbin-Watson } d- \\
\text { statistic }\end{array}$ & 1.959 & 1.881 & 2.011 & 2.084 \\
\hline $\begin{array}{l}\text { Portmanteau test } \\
\text { for white noise }(Q)\end{array}$ & 40.579 & 31.699 & 29.809 & 38.117 \\
\hline
\end{tabular}

Note. Cells contain the lags and signs of significant VAR coefficients with Granger causality $F$ value in parentheses. For Granger causality, the null hypothesis that the coefficients on all the lags of an endogenous variable are jointly zero is tested. n.s.: not significant, ${ }^{\circ}$ : significant on $10 \%$ level, ${ }^{*}$ : significant on $5 \%$ level, ${ }^{* *}$ : significant on $1 \%$ level, ${ }^{* * *}$ : significant on $.1 \%$ level. EI for general economy is the production index, EI number for employment is the unemployment rate, PE question for general economy: "How do you expect the general economic situation in this country to develop over the next 12 months?," PE question for employment: "How do you expect the number of people unemployed in this country to change over the next 12 months?"

${ }^{1}$ Deborah J. Blood and Peter Phillips, "Recession headline news, consumer sentiment, the state of the economy and presidential popularity: A time series analysis 1989-1993," International Journal of Public Opinion Research 7, no. 1 (1995), doi:10.1093/ijpor/7.1.2. 
${ }^{2}$ Brigitte Desroches and Marc-André Gosselin, "Evaluating threshold effects in consumer sentiment," Southern Economic Journal 70, no. 4 (2004), doi:10.2307/4135281.

3 Fabian Linden, "The consumer as forecaster," Public Opinion Quarterly 46, no. 3 (1982), doi:10.1086/268732; H. D. Wu et al., "The conditioned impact of recession news: A time-series analysis of economic communication in the United States, 1987-1996," International Journal of Public Opinion Research 14, no. 1 (2002), doi:10.1093/ijpor/14.1.19.

${ }^{4}$ Lutz M. Hagen, "Public Opinion and the Economy," in The SAGE Handbook of Public Opinion Research, ed. Wolfgang Donsbach and Michael W. Traugott (London: SAGE Publications Ltd, 2008), 527-33, 527. ${ }^{5}$ Werner Wirth et al., "Agenda building and setting in a referendum campaign: Investigating the flow of arguments among campaigners, the media, and the public," Journalism $\mathcal{E}$ Mass Communication Quarterly 87, no. 2 (2010), doi:10.1177/107769901008700207.

${ }^{6}$ G. C. Stone and Maxwell E. McCombs, "Tracing the time lag in Agenda-Setting," Journalism \& Mass Communication Quarterly 58, no. 1 (1981), doi:10.1177/107769908105800108.

${ }^{7}$ H. B. Haller and Helmut Norpoth, "Reality bites: News exposure and economic opinion," Public Opinion Quarterly 61, no. 4 (1997).

${ }^{8} \mathrm{Wu}$ et al., "The conditioned impact of recession news: A time-series analysis of economic communication in the United States, 1987-1996," 23.

9 Roy Behr and Shanto Iyengar, "Television news, real-world cues, and changes in the public agenda," Public Opinion Quarterly 49, no. 1 (1985).

${ }^{10} \mathrm{Wu}$ et al., "The conditioned impact of recession news: A time-series analysis of economic communication in the United States, 1987-1996"

${ }^{11}$ Deborah J. Blood and Peter C. B. Phillips, "Economic headline news on the agenda: New approaches to understanding causes and effects," in Communication and democracy, ed. Maxwell E. McCombs, Donald L. Shaw and David H. Weaver (Mahwah, N.J, London: L. Erlbaum, 1997), 97-114.

${ }^{12}$ For Germany: Hajo Boomgaarden, "The news media and economic voting in the 1998 German Bundestag election," Conference Papers -- International Communication Association, 2004; Frank Brettschneider, "Economic affairs, media coverage, and the public's perception of the economy in Germany," in Communication research and media science in Europe: Perspectives for research and academic training in Europe's changing media reality, ed. Angela Schorr, Mouton reader (Berlin: Mouton de Gruyter, 2003), 251-70; Sophie Wörsdorfer, "Wie die Wirtschaftsberichterstattung der Medien das Konsumentenvertrauen lenkt: Empirische Evidenzen für Deutschland, 1995-2005," Wirtschaft im Wandel 11, no. 11 (2005), accessed December 22, 2010, http://www.iwh-halle.de/d/publik/wiwa/11-05.pdf., for the U.S: Deborah J. Blood and Peter C. B. Phillips, "Economic headline news on the agenda: New approaches to understanding causes and effects," in Communication and democracy, ed. Maxwell E. McCombs, Donald L. Shaw and David H. Weaver (Mahwah, N.J, London: L. Erlbaum, 1997), 97-114; Dennis T. Lowry, “Network TV news framing of good vs. bad economic news under democrat and republican presidents: A lexical analysis of political bias," Journalism \& Mass Communication Quarterly 85, no. 3 (2008)., for South Korea: Youngkee Ju, "The asymmetry in economic news coverage and its impact on public perception in South Korea," International Journal of Public Opinion Research 20, no. 2 (2008), doi:10.1093/ijpor/edn021. ${ }^{13}$ Stuart N. Soroka, "Good news and bad news: Asymmetric responses to economic information," Journal of Politics 68, no. 2 (2006), doi:10.1111/j.1468-2508.2006.00413.x.

${ }^{14}$ Richard Nadeau et al., "Elite economic forecasts, economic news, mass economic judgments, and presidential approval," Journal of Politics 61, no. 1 (1999).

${ }^{15}$ Patrick M. Jablonski and John F. Daniele, "Variations in issue obtrusiveness and its impact on agenda building: The case of base realignment and closing," World Communication 27, no. 3 (1998).

${ }^{16}$ Martha A. Starr, "Consumption, sentiment, and economic news," Economic Inquiry 50, no. 4 (2012): 1106, doi:10.1111/j.1465-7295.2010.00346.x.

${ }^{17}$ Soroka, "Good news and bad news: Asymmetric responses to economic information" 
${ }^{18}$ Nadeau et al., “Elite economic forecasts, economic news, mass economic judgments, and presidential approval"

${ }^{19}$ Marko Bachl, "Media effects on perceptions of the state of the economy in Germany: Evidence from a Time Series Analysis 1998 - 2007," Conference Papers -- International Communication Association, 2009; Blood and Phillips, "Recession headline news, consumer sentiment, the state of the economy and presidential popularity," Frank Brettschneider, "Economic affairs, media coverage, and the public's perception of the economy in Germany," in Communication research and media science in Europe: Perspectives for research and academic training in Europe's changing media reality, ed. Angela Schorr, Mouton reader (Berlin: Mouton de Gruyter, 2003), 251-70; Mark Doms and Norman Morin, "Consumer sentiment, the economy, and the news media," Lena Dräger, "Inflation perceptions and expectations in Sweden - Are media reports the 'missing link'?," accessed February 17, 2012, http://www.kof.ethz.ch/de/publikationen/p/kof-working-papers/273/; Kirby Goidel et al., "Sources of economic news and economic expectations," American Politics Research 38, no. 4 (2010), doi:10.1177/1532673X09355671; Lutz M. Hagen, Konjunkturnachrichten, Konjunkturklima und Konjunktur: Wie sich die Wirtschaftsberichterstattung der Massenmedien, Stimmungen der Bevölkerung und die aktuelle Wirtschaftslage wechselseitig beeinflussen. Eine transaktionale Analyse (Köln: von Halem, 2005); Joe B. Hester and Rhonda Gibson, "The economy and second level agenda setting: A time-series analysis of economic news and public opinion about the economy," Journalism \& Mass Communication Quarterly 80, no. 1 (2003); Ju, "The asymmetry in economic news coverage and its impact on public perception in South Korea," Michael J. Lamla, Sarah M. Lein, and Jan-Egbert Sturm, "News and Sectoral Comovement: KOF Working Paper No. 183," KOF Swiss Economic Institute, accessed January 4, 2012, http://www.kof.ethz.ch/de/publikationen/p/kof-working-papers/183/; Wu et al., "The conditioned impact of recession news: A time-series analysis of economic communication in the United States, 1987-1996"

${ }^{20}$ Alan S. Blinder and Alan B. Krueger, "What does the public know about economic policy, and how does it know it? CEPS Working Paper No. 99," accessed December 5, 2011, https://www.princeton.edu/ceps/workingpapers/99blinderkrueger.pdf.Adam Shehata and Jesper Strömbäck, "Not (Yet) a new era of minimal effects: A study of agenda setting at the aggregate and individual levels," International Journal of Press/Politics 18, no. 2 (2013), doi:10.1177/1940161212473831.

${ }^{21}$ Behr and Iyengar, "Television news, real-world cues, and changes in the public agenda," Linden, "The consumer as forecaster"

${ }^{22}$ Richard W. Blood, "Unobtrusive issues in the agenda-setting role of the press" (Dissertation Paper 64, Mass Communications, Syracuse University, 1981); Harold G. Zucker, "The variable nature of news media influence," in Communication Yearbook 2, vol. 2, ed. Brent D. Rubin (New Brunswick, NJ: Transaction Publishers, 1978), 225-45, 2.

${ }^{23}$ David P. Demers et al., "Issue obtrusiveness and the agenda-setting effects of national network news," Communication Research 16, no. 6 (1989): 798, doi:10.1177/009365089016006004. Jablonski and Daniele, "Variations in issue obtrusiveness and its impact on agenda building: The case of base realignment and closing," The authors highlight that issue obtrusiveness should not be confused with issue salience. The audience's attributions of salience are influenced by media coverage. In contrast, attributions of obtrusiveness are a result of people's direct experiences with an issue, which is independent from media coverage.

${ }^{24} \mathrm{G}$. Lee, “Reconciling 'cognitive priming' vs 'obtrusive contingency' hypotheses: An analytical model of media agenda-setting effects," International Communication Gazette 66, no. 2 (2004): 152, doi:10.1177/0016549204041475.

${ }^{25}$ Youngkee Ju, "Obtrusiveness and negative bias: Issue attribute's influence on the asymmetric news coverage of the economy," Conference Papers -- International Communication Association, 2011. Defines GDP as unobtrusive. Examples of economic issues as obtrusive can be found inDemers et al., "Issue obtrusiveness and the agenda-setting effects of national network news," Demers et al., "Issue obtrusiveness and the agenda-setting effects of national network news," 796-7. 
${ }^{26}$ Diana C. Mutz, "Mass media and the depoliticization of personal experience," American Journal of Political Science 36, no. 2 (1992), doi:10.2307/2111487, http://www.jstor.org/stable/2111487.

${ }^{27}$ Lutz Hagen, "Agenda-setting unemployment: Media-effects upon perceptions of sociotropic versus egotropic aspects of issue-salience," Conference Papers -- International Communication Association, 2004.

28 Ulrich Kater, Die 100 wichtigsten Konjunkturindikatoren weltweit, 2nd ed. (Wiesbaden: Cometis, 2008).

${ }^{29}$ Haller and Norpoth, "Reality bites: News exposure and economic opinion"

${ }^{30}$ Birgit Krause and Benjamin Fretwurst, "Kurzfristige Agenda-Setting-Effekte von Fernsehnachrichten: Eine Zeitreihenanalyse am Beispiel Ausländerfeindlichkeit und Rechtsradikalismus," in Fortschritte der politischen Kommunikationsforschung: Festschrift für Lutz Erbring, ed. Birgit Krause, Benjamin Fretwurst and Jens Vogelgesang, Forschung Kommunikation (Wiesbaden: VS Verlag, 2007), 171-96; Markus Maurer, "Das Paradox der Medienwirkungsforschung: Verändern Massenmedien die Bevölkerungsmeinung, ohne Einzelne zu beeinflussen?," Publizistik 49, no. 4 (2004), doi:10.1007/s11616-004-0108-y; Hagen, Konjunkturnachrichten, Konjunkturklima und Konjunktur. The authors state that the more consonant news coverage is, the stronger are the news effects on the public. If the media coverage is not consonant across news outlets, varying opinions can develop depending on the way individuals use the media. Follow-up communication will also transfer differing opinions. Hence, aggregation on the total public on national level would dilute differences in public opinion and underestimate news effects. Therefore, the interaction between NT and NC is an important moderating variable for news effects on the public and is considered in this study.

${ }^{31}$ Shehata and Strömbäck, "Not (Yet) a new era of minimal effects: A study of agenda setting at the aggregate and individual levels," 242, 250.

32 Stuart N. Soroka, "When does news matter? Public agenda-setting for unemployment," accessed March 18, 2014, http://www.nuffield.ox.ac.uk/Politics/papers/2002/w7/soroka.pdf, 7.

${ }_{33} \mathrm{Mutz}$, "Mass media and the depoliticization of personal experience"

${ }^{34}$ Haller and Norpoth, "Reality bites: News exposure and economic opinion"

35 Oliver Quiring and Mathias Weber, "Between usefulness and legitimacy: Media coverage of governmental intervention during the financial crisis and selected effects," International Journal of Press/Politics 17, no. 3 (2012), doi:10.1177/1940161212442957.

${ }^{36} \mathrm{H}$. D. Wu and Renita Coleman, "Advancing agenda-setting theory: The comparative strength and new contingent conditions of the two levels of agenda-setting effects," Journalism \& Mass Communication Quarterly 86, no. 4 (2009), doi:10.1177/107769900908600404.

${ }^{37}$ Hester and Gibson, "The economy and second level agenda setting"

${ }^{38} \mathrm{Wu}$ et al., "The conditioned impact of recession news: A time-series analysis of economic communication in the United States, 1987-1996"

${ }^{39}$ Hester and Gibson, "The economy and second level agenda setting," Barbara Headrick and David J. Lanoue, "Attention, asymmetry, and government popularity in Britain," Western Political Quarterly 44, no. 1 (1991), doi:10.2307/448747.

${ }^{40}$ Blood, "Unobtrusive issues in the agenda-setting role of the press,"; Jörg Matthes, "Need for orientation as a predictor of agenda-setting effects: Causal evidence from a two-wave panel study," International Journal of Public Opinion Research 20, no. 4 (2008), doi:10.1093/ijpor/edn042.

${ }^{41}$ Jan Grossarth-Maticek and Johannes Mayr, "Medienberichte als Konjunkturindikator," accessed February 17, 2012, $\quad$ http://www.cesifo-group.de/portal/page/portal/ifoContent/N/pr/prPDFs/Schnelldienst2008PDF/R-Wort-Indikator-0108.pdf.

${ }^{42} \mathrm{Wu}$ et al., "The conditioned impact of recession news: A time-series analysis of economic communication in the United States, 1987-1996"

${ }^{43}$ Kevin D. Salyer and Steven M. Sheffrin, "Spotting sunspots: Some evidence in support of models with self-fulfilling prophecies," Journal of Monetary Economics 42, no. 3 (1998), doi:10.1016/S03043932(98)00037-3. 
${ }^{44}$ Roger E. A. Farmer, The macroeconomics of self-fulfilling prophecies, 2nd ed (Cambridge, Mass: MIT Press, 1999); Sharon G. Harrison and Mark Weder, "Did sunspot forces cause the Great Depression?," Journal of Monetary Economics 53, no. 7 (2006), doi:10.1016/j.jmoneco.2005.07.018.

${ }^{45}$ Lilia Karnizova, "The spirit of capitalism and expectation-driven business cycles," Journal of Monetary Economics 57, no. 6 (2010): 739, doi:10.1016/j.jmoneco.2010.06.002.

46 Seonghwan Oh and Michael Waldman, "The macroeconomic effects of false announcements," Quarterly Journal of Economics 105, no. 4 (1990).

47 Shanto Iyengar and Donald Ray Kinder, News that matters: Television and American opinion, American politics and political economy series (Chicago: University of Chicago Press, 1987).

48 Icek Ajzen and Martin Fishbein, "Attitude-behavior relations: A theoretical analysis and review of empirical research," Psychological Bulletin 84, no. 5 (1977), doi:10.1037/0033-2909.84.5.888. Icek Ajzen, "Nature and operation of attitudes," Annual Review of Psychology 52, no. 1 (2001), doi:10.1146/annurev.psych.52.1.27.

${ }^{49}$ Matthias W. Uhl, "And action: TV sentiment and the US consumer," Applied Economics Letters 19, no. 11 (2012), doi:10.1080/13504851.2011.613739.

${ }^{50}$ Kater, Die 100 wichtigsten Konjunkturindikatoren weltweit.

${ }^{51}$ Daniel C. Hallin and Paolo Mancini, Comparing media systems: Three models of media and politics, Communication, society and politics (Cambridge: Cambridge University Press, 2004).

52 Birgit van Eimeren and Christa-Maria Ridder, "Trends in der Nutzung und Bewertung der Medien 1970 bis 2010: Ergebnisse der ARD/ZDF-Langzeitstudie Massenkommunikation," Media Perspektiven, no. 1 (2011).

${ }^{53}$ Frank Brettschneider, "Economic affairs, media coverage, and the public's perception of the economy in Germany," in Communication research and media science in Europe: Perspectives for research and academic training in Europe's changing media reality, ed. Angela Schorr, Mouton reader (Berlin: Mouton de Gruyter, 2003), 251-70; Michaela Maier, Georg Ruhrmann, and Karin Stengel, "Der Wert von Nachrichten im deutschen Fernsehen: Inhaltsanalyse von TV-Nachrichten im Jahr 2007," accessed November 1, 2012, http://www.lfm-nrw.de/fileadmin/lfm-nrw/Pressemeldungen/nachrichtenanalyse_1992-2007.pdf;

Frank Marcinkowski and Mirko Marr, "Medieninhalte und Medieninhaltsforschung," in Einführung in die Publizistikwissenschaft, ed. Heinz Bonfadelli, Otfried Jarren and Gabriele Siegert, 3rd ed., UTB für Wissenschaft;Kommunikationswissenschaft 2170 (Bern: Verlag Paul Haupt, 2010), 477-516; Oliver Quiring, Wirtschaftsberichterstattung und Wahlen (Konstanz: UVK, 2004).

${ }^{54}$ Robert G. Picard, "Environmental and market changes driving strategic planning in media firms," in Strategic responses to media market changes, ed. Robert G. Picard, JIBS Research report Series (Jönköping: Jönköping International Business School, 2004), 1-17.

55 Beate Schirwitz, "A comprehensive German business cycle chronology," Empirical Economics 37, no. 2 (2009), doi:10.1007/s00181-008-0233-y. This article analyses German recessions between 1970 and 2006 according to the "newspaper" definition with at least two consecutive quarters of negative GDP growth. The 2003/4 and the 2008/9 recessions are confirmed by the Federal Statistical Office in Germany: Statistisches Bundesamt, "Bruttoinlandsprodukt 2011 für Deutschland," accessed March 22, 2014, https://www.destatis.de/DE/PresseService/Presse/Pressekonferenzen/2012/BIP2011/Pressebro-

schuere_BIP2011.pdf?_blob=publicationFile; Norbert Räth, "Rezessionen in historischer Betrachtung," Wirtschaft und Statistik, no. 3 (2009), accessed March 22, 2014, https://www.destatis.de/DE/Publikationen/WirtschaftStatistik/Monatsausgaben/WistaMaerz09.pdf?_blob=publicationFile. In the 2003/04 crisis, GDP growth was slightly negative (-.4\%), in the 2008/09 crisis, the GDP decline was severe ($5.1 \%$ ) representing the largest GDP decline in Germany's postwar period.

${ }^{56}$ Camille Zubayr and Heinz Gerhard, "Tendenzen im Zuschauerverhalten: Fernsehgewohnheiten und Fernsehreichweiten im Jahr 2004," Media Perspektiven, no. 3 (2005); Camille Zubayr and Heinz Gerhard, "Tendenzen im Zuschauerverhalten: Fernsehgewohnheiten und Fernsehreichweiten im Jahr 2011," Media Perspektiven, no. 3 (2012). 
${ }^{57}$ Zubayr and Gerhard, "Tendenzen im Zuschauerverhalten," Zubayr and Gerhard, "Tendenzen im Zuschauerverhalten"

${ }^{58}$ Sold circulation of BILD refers to Quarter 4 of each year and is retrieved from IVW, "Tageszeitungen Gesamtliste," Informationsgemeinschaft zur Feststellung der Verbreitung von Werbeträgern e. V., accessed January 10, 2013, www.ivw.eu.

${ }^{59}$ Frank Marcinkowski and Mirko Marr, "Medieninhalte und Medieninhaltsforschung," in Einführung in die Publizistikwissenschaft, ed. Heinz Bonfadelli, Otfried Jarren and Gabriele Siegert, 3rd ed., UTB für Wissenschaft;Kommunikationswissenschaft 2170 (Bern: Verlag Paul Haupt, 2010), 477-516, 489.

${ }^{60}$ Ulrike Klein, "Tabloidised political coverage in BILD-Zeitung," Javnost-The Public 5, no. 3 (1998), accessed September 9, 2013, http://javnost-thepublic.org/article/1998/3/6/.

${ }^{61}$ Hagen, Konjunkturnachrichten, Konjunkturklima und Konjunktur.

${ }^{62}$ Adam Shehata, "Unemployment on the agenda: A panel study of agenda-setting effects during the 2006 Swedish national election campaign," Journal of Communication 60, no. 1 (2010), doi:10.1111/j.14602466.2009.01475.x.

${ }^{63}$ Economic news topics comprise the categories (1) state, context, and location (economic policy, national debt, laws, orders, bureaucracy, general ability to compete, employment protection, environmental specifications, protection against dismissal, business tax, income tax, value added tax, subsidies, tariff policy, infrastructure, foreign direct investments), (2) the general economy, (3) employment, (4) consumer and business sentiment, (5) productivity and labor costs, (6) prices and inflation, (7) currency, (8) external trade, (9) GNP and GDP, (10) order entries, (11) income, and (12) minor topics (bankruptcies, start-ups, investments, innovations).

${ }^{64}$ Separate regressions with NT and NC on the general economy and employment per news outlet reveal linear and stationary relations according to the procedure suggested by Robert F. Engle and C. W. J. Granger, "Co-integration and error correction: Representation, estimation, and testing," Econometrica 55, no. 2 (1987), doi:10.2307/1913236. The residuals of the regressions for NT and NC are generated by a stationary process according to the augmented Dickey-Fuller test. Therefore, long-term relations exist between NT and NC among the four news outlets. However, the tabloid newspaper BILD differs from the TV news outlets in NV. After 2007 the volume of economic news decreases in BILD, but increases in the TV news shows. But this decrease is reflected in the NV's sum.

65 Media Tenor, "Working standards: Media content analysis," accessed February 12, 2013, http://www.mediatenor.com/mca_work_standards.php.

${ }^{66}$ Marcel Garz, "Job insecurity perceptions and media coverage of labor market policy," Journal of Labor Research 33, no. 4 (2012), doi:10.1007/s12122-012-9146-9; Grossarth-Maticek and Mayr, "Medienberichte als Konjunkturindikator" Lamla, Lein and Sturm, "News and Sectoral Comovement" Michael J. Lamla and Sarah M. Lein, "The role of media for consumers' inflation expectation formation: KOF Working Paper Nr. 201," accessed December 22, 2011, http://kof.ethz.ch/de/publikationen/p/kof-working-papers/201/; Wörsdorfer, "Wie die Wirtschaftsberichterstattung der Medien das Konsumentenvertrauen lenkt"

${ }^{67}$ Hagen, Konjunkturnachrichten, Konjunkturklima und Konjunktur, 134.

${ }^{68}$ Directorate-General f. E. a. F. A. European Commission, "European economy: The joint harmonised EU programme of business and consumer surveys," Special Report No 5 / 2006, accessed January 22, 2013, http://ec.europa.eu/economy_finance/publications/publication7568_en.pdf, 3 .

69 "Business and consumer survey: Metadata overview," accessed January 22, 2013, http://ec.europa.eu/economy_finance/db_indicators/surveys/documents/metadata2/metadata_de_cons_en.pdf.

${ }^{70}$ European Commission and Directorate-General for Economic and Financial Affairs, "The joint harmonised EU programme of business and consumer surveys: User guide," accessed January 8, 2013, http://ec.europa.eu/economy_finance/db_indicators/surveys/documents/userguide_en.pdf, 47.

${ }^{71}$ European Commission and Directorate-General for Economic and Financial Affairs, "The joint harmonised EU programme of business and consumer surveys: User guide," 48. 
72 Christopher Sims, "Macroeconomics and reality," Econometrica 48, no. 1 (1980), doi:10.2307/1912017.

${ }^{73}$ Clive W. Granger, "Investigating causal relations by econometric models and cross-spectral methods," Econometrica 37, no. 3 (1969).

${ }_{74}$ Dimitrios Asteriou and Stephen G. Hall, Applied econometrics, 2nd ed. (Basingstoke: Palgrave Macmillan, 2011).

75 Shehata, "Unemployment on the agenda: A panel study of agenda-setting effects during the 2006 Swedish national election campaign," Shehata and Strömbäck, "Not (Yet) a new era of minimal effects: A study of agenda setting at the aggregate and individual levels," Wu et al., "The conditioned impact of recession news: A time-series analysis of economic communication in the United States, 1987-1996," 76 Jeffrey M. Wooldridge, Introductory econometrics: A modern approach, 4th ed. (Mason Ohio: South Western cengage learning, 2009); Engle and Granger, "Co-integration and error correction: Representation, estimation, and testing," 261.

77 Also no unit root in economic headline NT was found in Deborah J. Blood and Peter C. B. Phillips, "Economic headline news on the agenda: New approaches to understanding causes and effects," in Communication and democracy, ed. Maxwell E. McCombs, Donald L. Shaw and David H. Weaver (Mahwah, N.J, London: L. Erlbaum, 1997), 97-114.

78 Walter Enders, Applied econometric time series, 3rd ed, Wiley series in probability and statistics (Hoboken, NJ: Wiley, 2010).

${ }^{79}$ Soroka, "Good news and bad news: Asymmetric responses to economic information," Soroka, "When does news matter?"

${ }^{80}$ Behr and Iyengar, "Television news, real-world cues, and changes in the public agenda," Wu et al., "The conditioned impact of recession news: A time-series analysis of economic communication in the United States, 1987-1996"

81 Soroka, "Good news and bad news: Asymmetric responses to economic information,"; Wu et al., "The conditioned impact of recession news: A time-series analysis of economic communication in the United States, 1987-1996"

82 R. K. Goidel and R. E. Langley, "Media coverage of the economy and aggregate economic evaluations: Uncovering evidence of indirect media effects," Political Research Quarterly 48, no. 2 (1995): 325, doi:10.1177/106591299504800205.

83 Soroka, "Good news and bad news: Asymmetric responses to economic information"

${ }^{84} \mathrm{Wu}$ et al., "The conditioned impact of recession news: A time-series analysis of economic communication in the United States, 1987-1996"

${ }^{85}$ Hester and Gibson, "The economy and second level agenda setting," Ju, "The asymmetry in economic news coverage and its impact on public perception in South Korea," Soroka, "Good news and bad news: Asymmetric responses to economic information"

${ }^{86}$ Guy Golan and Wayne Wanta, "Second-level agenda setting in the new hampshire primary: A comparison of coverage in three newspapers and public perceptions of candidates," Journalism E Mass Communication Quarterly 78, no. 2 (2001), doi:10.1177/107769900107800203.

${ }^{87}$ Shehata and Strömbäck, "Not (Yet) a new era of minimal effects: A study of agenda setting at the aggregate and individual levels"

${ }^{88}$ Blinder and Krueger, "What does the public know about economic policy, and how does it know it?"

${ }^{89} \mathrm{Wu}$ et al., "The conditioned impact of recession news: A time-series analysis of economic communication in the United States, 1987-1996"

${ }^{90}$ Kater, Die 100 wichtigsten Konjunkturindikatoren weltweit. 